University of Nebraska - Lincoln

DigitalCommons@University of Nebraska - Lincoln

Faculty Publications from the Harold W. Manter Laboratory of Parasitology

2008

\title{
Age Distribution and Seasonal Dynamics of Abomasal Helminths in Wild Red Deer from Central Spain
}

\author{
Mónica Santín-Durán \\ Universidad Complutense de Madrid \\ José M. Alunda \\ Universidad Complutense de Madrid \\ Eric P. Hoberg \\ National Parasite Collection, Agricultural Research Service, United States Department of Agriculture, \\ ehoberg@ggpl.arsusda.gov \\ Concepción de la Fuente \\ Universidad Complutense de Madrid, cfuente2@vet.ucm.es
}

Follow this and additional works at: https://digitalcommons.unl.edu/parasitologyfacpubs

Part of the Parasitology Commons

Santín-Durán, Mónica; Alunda, José M.; Hoberg, Eric P.; and de la Fuente, Concepción, "Age Distribution and Seasonal Dynamics of Abomasal Helminths in Wild Red Deer from Central Spain" (2008). Faculty Publications from the Harold W. Manter Laboratory of Parasitology. 643.

https://digitalcommons.unl.edu/parasitologyfacpubs/643

This Article is brought to you for free and open access by the Parasitology, Harold W. Manter Laboratory of at DigitalCommons@University of Nebraska - Lincoln. It has been accepted for inclusion in Faculty Publications from the Harold W. Manter Laboratory of Parasitology by an authorized administrator of DigitalCommons@University of Nebraska - Lincoln. 


\title{
AGE DISTRIBUTION AND SEASONAL DYNAMICS OF ABOMASAL HELMINTHS IN WILD RED DEER FROM CENTRAL SPAIN
}

\author{
Mónica Santín-Durán`, José M. Alunda, Eric P. Hoberg†, and Concepción de la Fuente \\ Departamento de Sanidad Animal, Facultad de Veterinaria, Universidad Complutense de Madrid, 28040 Madrid, Spain. \\ e-mail: cfuente2@vet.ucm.es
}

\begin{abstract}
A study on age distribution and seasonal dynamics of abomasal helminths in wild red deer was conducted in central Spain, by monthly samplings of fawns $(<1 \mathrm{yr})$, subadult $(1-2 \mathrm{yr})$, and adult $(>2 \mathrm{yr})$ animals. Both intensity and prevalence of abomasal parasitism were higher in older animals, particularly in males. A bimodal pattern for intensity of infection by gastrointestinal parasites was observed. Maximum values attained in winter and summer may be related to variation in climate and the shifting availability of forage resources. The pattern was largely due to the contribution of Spiculopteragia asymmetrica/Spiculopteragia quadrispiculata, whereas the other species found (Ostertagia leptospicularis/Ostertagia kolchida and Ostertagia drozdzi/Ostertagia ryjikovi) occurred with lower prevalence and intensity of infection. Among these ostertagiines, the ratio for major and minor morphotypes of males of respective species and the relative abundance of males and females were stable through the annual cycle.
\end{abstract}

Red deer (Cervus elaphus Linnaeus) are the most abundant and widely distributed cervids in Spain. During recent decades, populations of red deer and other cervids have expanded. These population increases have been driven by the abandonment of rural settlements (Tellería and Sáez-Royuela, 1984), the growing interest in wildlife conservation, and the use of wildlife resources for alternative economic development (hunting, ecological tourism).

Red deer host a variety of endoparasites, particularly nematodes, and numerous studies have documented helminth biodiversity in European countries with significant populations of this cervid (Jančev, 1979; Hernández et al., 1980; Barth and Matzke, 1984; Batty et al., 1987; Dróżdż et al., 1992; Ambrosi et al., 1993; Zaffaroni et al., 1996; Dróżdż et al., 1997; Rossi et al., 1997). In most cases, however, these reports do not provide information on the seasonal dynamics of helminth infections or the variation in abundance, prevalence, or diversity in relation to age and sex of hosts.

On these grounds, it was considered relevant to explore the dynamics of parasitism, in particular the potential influence of age and seasonality in transmission and occurrence of helminth faunas in red deer. Here, we present the first study carried out on the Iberian Peninsula that provides empirical data and a discussion of variation in abomasal helminths during a complete annual cycle among discrete age classes of red deer. Our current study builds on foundations for helminth diversity established through survey and inventory for abomasal nematodes in sympatric red deer and fallow deer from central and western Spain (Santín-Durán et al., 2004).

\section{MATERIALS AND METHODS}

The study area, Quintos de Mora (Toledo), is a government-owned and -managed park located in central Spain $\left(39^{\circ} 25^{\prime} \mathrm{N}, 4^{\circ} 04^{\prime} \mathrm{W}\right)$, and consists of 6,864 ha, divided in 2 areas, a plain $800 \mathrm{~m}$ above sea level (asl) crossed by the Las Navas River, and a surrounding mountainous region, reaching $1,235 \mathrm{~m}$ asl. The climate is Mediterranean, with a dry season (June-September) and maximum rainfall in spring and early

Received 31 October 2006; revised 5 July 2007; accepted 14 February 2008.

* Present address: Environmental Microbial Safety Laboratory, USDA, ARS, BARC-East, Building 173, Beltsville, Maryland 20705.

† U.S. National Parasite Collection, and Animal Parasitic Diseases Laboratory, USDA, ARS, BARC-East, Building 1180, Beltsville, Maryland 20705 . winter (Fig. 1). The vegetation is a Mediterranean forest in varying stages of succession (Álvarez et al., 1991), with Pinus pinea, Pinus pinaster, Quercus rotundifolia, and Quercus faginea as the predominant trees, and a shrub understory composed of Arbutus unedo, Phillyrea angustifolia, Cistus ladanifer, and Erica spp. Habitat is managed for red deer and in 1993 foraging areas were augmented with artificial pastures (632 ha with just $1 / 3$ of the surface sown) to cope with seasonally low primary production. These pastures were closed to the animals throughout the year, except in summer, when deer were allowed to graze (Sanz de la Torre et al., 1993).

Several species of game animals are found within the park boundaries, including red deer, fallow deer Dama dama (Linnaeus), roe deer Capreolus capreolus (Linnaeus), mufflon Ovis musimon (=Ovis aries Linnaeus), and wild boar Sus scrofa (Linnaeus). Taxonomy for ungulate species follows Wilson and Reeder (1993). Red and fallow deer are by far the most common, with populations of $C$. elaphus estimated at approximately 2,100 individuals $(0.3 \mathrm{deer} / \mathrm{ha})$, and an estimated density of fallow deer of $0.03 \mathrm{deer} / \mathrm{ha}$ (Álvarez, 1988). Populations of all ungulates are essentially wild, and treatment with anthelmintics or other intervention has not occurred. There are no domestic animals in this area, and the population of cervids has remained isolated by a continuous wall surrounding the entire park.

Red deer (141) were collected at Quintos de Mora (Toledo) during selective hunting carried out in the park from October 1994 to February 1995. Additionally, to complete the yearly sampling, some animals (at least 3 per age group/mo when possible) were shot during the nonhunting season (March-September 1995) by park wardens. Animals were partitioned in 3 groups according to age: fawns $<1 \mathrm{yr}$, yearlings or subadults in the second year, and adults $>2$ yr (Table I). Sex was determined and considered as a variable for adult deer $(>2 \mathrm{yr})$, but not for fawns or yearlings.

All animals were subjected to standard necropsy procedures. Each abomasum was isolated in situ with the use of a ligation between the small intestine and abomasum, after which the abomasum was removed and processed for recovery and enumeration of adult nematodes (Ministry of Agriculture, Fisheries, and Food, 1971). Abomasal contents and washes were combined and aliquoted, with $2 \times 10 \%$ duplicate aliquots being collected and preserved in ethanol $(70 \%)$ or fixed in phosphatebuffered formalin (5\%). Abomasal digestion for recognition of possible populations of arrested fourth-stage larvae for respective species of ostertagiines was not conducted. The total number of worms of each species was calculated by identifying and counting male and female worms in a $10 \%$ aliquot of the contents from each animal. Specimens were studied as temporary whole mounts cleared in phenol-alcohol (80 parts melted phenol crystals and 20 parts absolute ethanol) and examined with interference contrast light microscopy. Species identification was conducted as described previously (Santín-Durán et al., 2004). Concepts and taxonomy for polymorphic males among genera and species of abomasal nematodes in the Ostertagiinae follow Dróżdż (1995).

The prevalence, abundance, and mean intensity were calculated as specified in Margolis et al. (1982). The frequency of each species, i.e. (number of nematodes, males and females, of 1 species/total number of nematodes of all species) $\times 100$, was established for each animal on 


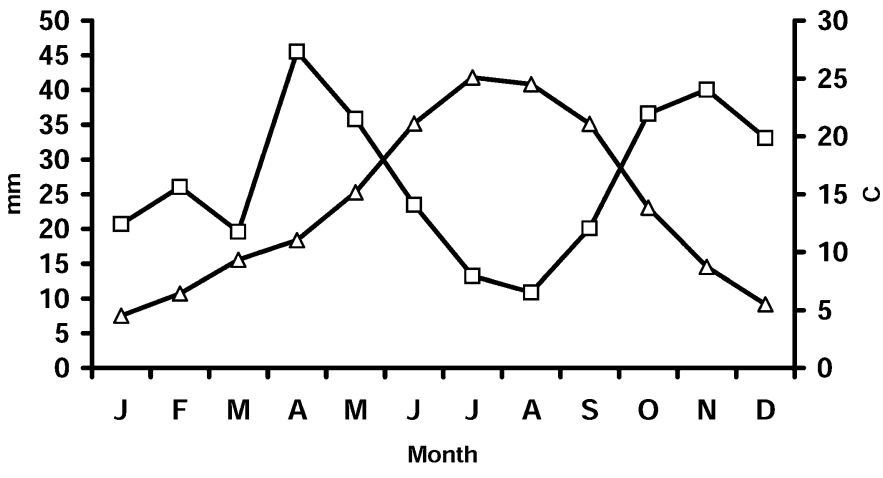

$\rightarrow-$ Precipitation $\rightarrow-$ Temperature

FIGURE 1. Monthly average of precipitation $(\mathrm{mm})$ and temperature (C) in Mora de Toledo Meteorological Station (Toledo, Spain) from 1980 to 1992 .

the basis of all the worms found in the aliquot; a mean frequency was calculated from all deer infected. In the same manner, the ratios of major:minor morphotypes for the pair of males representing each species of ostertagiine and the percentage of females of each species were calculated.

Data were analyzed at the UCM Computing Center (CPD) with the use of BMDP statistical software (Dixon, 1993). Statistics included parametric (Student's $t$-test, analysis of variance) and nonparametric tests (chi-square test, correlation). The Welch test (alternative $t$-test) was used to compare means when standard deviations were not equal between compared groups. Duncan and Tukey multiple comparison test were performed when the $P$ value was less than 0.05 . The term significant refers to statistical significance at $P \leq 0.05$.

\section{RESULTS}

Abomasal helminth infections were prevalent in the deer examined. Considering all the age groups, sexes, and seasons sampled, $92.9 \%$ of the animals were infected (131 of 141). Given the high prevalence, no essential differences were found between overall abundance (513.7 \pm 427.5 nematodes/deer) and mean intensity $(552.9 \pm 418.3$ nematodes/deer infected).

Spiculopteragia asymmetrica (Ware, 1925)/Spiculopteragia quadrispiculata (Jansen, 1958) was the most frequent species found in the abomasum of infected red deer $(n=131)$, and represented an average percentage of $86.7 \pm 14.8$ of the total abomasal worm populations in each host. Ostertagia leptospicularis (Assadov, 1953)/Ostertagia kolchida (Popova, 1937) and Ostertagia drozdzi (Jančev, 1977)/Ostertagia ryjikovi (Jančev, 1977) followed, with percentages of $10.1 \pm 13.2$ and $3.2 \pm 5.4$, respectively. Adult red deer had a higher percentage of $S$. asymmetrica/S. quadrispiculata in their abomasa than young animals $(P=0.0117)$. Ostertagia leptospicularis/O. kolchida comprised a greater proportion of the nematode population in yearlings, followed by adults; the lowest percentage of this species was found in fawns $(P=0.0156)$. However, fawns showed a significantly higher percentage of $O$. drozdzi/O. ryjikovi than yearlings and adults $(P=0.0004)$. Moreover, the percentage of $O$. drozdzi/O. ryjikovi clearly decreased with increasing age of the animals $(7.7 \pm 8.8$ in fawns vs. $1.5 \pm 3.2$ in adults $)$. No differences were observed between adult males and females $(P>$ $0.05)$ in the percentage that each sex represented in the total nematode population.

No seasonal fluctuations were observed for S. asymmetrical
TABLE I. Number of red deer examined per group in each season.

\begin{tabular}{lrrrrr}
\hline & & \multicolumn{5}{c}{ Seasons } \\
\cline { 3 - 6 } & animals & Fall & Winter & Spring & Summer \\
\hline Age groups & & & & & \\
$\quad<1$ yr & 30 & 11 & 8 & 10 & 1 \\
$1-2$ yr & 30 & 18 & 5 & 1 & 6 \\
$>2$ yr & 81 & 24 & 23 & 15 & 19 \\
Sex* & & & & & \\
Males & 39 & 11 & 11 & 8 & 9 \\
Females & 42 & 13 & 12 & 7 & 10 \\
Total & 141 & 53 & 36 & 26 & 26 \\
\hline
\end{tabular}

* Only adult red deer were considered.

$S$. quadrispiculata in the percentage that it represented of the total worm population in infected hosts $(P=0.1590)$. Nevertheless, we found significant differences among age groups in fall $(P=0.0737)$ and winter $(P=0.0072)$, and in both seasons they were related to the greater percentage of $S$. asymmetrical $S$. quadrispiculata occurring in adults. Slight differences were found for O. leptospicularis/O. kolchida between seasons, although they were significant $(P=0.0051)$, with the maximum percentage in fall and minimum in winter $(13.0 \pm 11.8$ vs. 5.9 \pm 6.0 ). However, there were no differences in the percentage of $O$. leptospicularis/O. kolchida related with age or sex of red deer in any season $(P>0.05)$. For $O$. drozdzilO. ryjikovi, a clear seasonal pattern was observed $(P=0.0008)$, with higher percentages in fall and winter $(4.2 \pm 5.8$ and $4.9 \pm 7.2$, respectively) than in spring and summer $(1.0 \pm 2.0$ and $1.6 \pm$ 2.5 , respectively), in which $O$. drozdzi/O. ryjikovi practically disappeared. Moreover, percentages were greater in fawns than in yearlings and adults, showing the latter by far the lowest values during the annual cycle. These differences in the percentage of $O$. drozdzi/O. ryjikovi among age groups were significant in fall, winter, and spring $(P<0.05)$.

Spiculopteragia asymmetrica/S. quadrispiculata, found in 130 of $141(92.2 \%)$ deer examined, was the most prevalent species; mean intensity was $479.7 \pm 361.4$ nematodes/deer. Significant differences were observed among age groups in the prevalence of $S$. asymmetrica/S. quadrispiculata $(P=0.0001)$ (Table II). No differences were observed among age classes for mean intensity, although fawns showed mean intensity much lower than those observed in yearlings and adults.

Ostertagia leptospicularis/O. kolchida was present in 99 of $141(70.2 \%)$ red deer; mean intensity was $76.4 \pm 90.2$ nematodes/deer. Significant variation was evident among age groups in the prevalence and mean intensity of $O$. leptospicularis $/ O$. kolchida $(P<0.05)$, with fawns showing the lowest levels of infection (Table II).

Ostertagia drozdzi/O. ryjikovi was present in 63 of 141 (44.7\%); mean intensity was $39.84 \pm 38.7$ nematodes/animal. Adult deer showed significantly $(P<0.05)$ lower prevalence, although not intensity, of $O$. drozdzi/O. ryjikovi in yearlings and fawns (Table II).

Prevalence of S. asymmetrica/S. quadrispiculata did not display any variation related to the season, and mean intensity exhibited a bimodal profile in adults. The low number of available samples of fawns in summer and yearlings in spring pre- 
TABLE II. Prevalence (\%) and mean intensity ( \pm SD) of Spiculopteragia asymmetrica/Spiculopteragia quadrispiculata, Ostertagia leptospicularis/ Ostertagia kolchida, and Ostertagia drozdzi/Ostertagia ryjikovi in different age groups of red deer.

\begin{tabular}{|c|c|c|c|c|}
\hline & & $<1-\mathrm{yr}$ & $1-2-y r$ & $>2-y r$ \\
\hline O. drozdzi/O. ryjikovi & $\begin{array}{l}\text { Prevalence } \\
\text { Mean intensity }\end{array}$ & $\begin{array}{l}50^{*} \\
52 \pm 53.3\end{array}$ & $\begin{array}{c}70^{*} \\
42.9 \pm 37.4\end{array}$ & $\begin{array}{c}33.3^{*} \\
30.7 \pm 27.9\end{array}$ \\
\hline
\end{tabular}

* Significant differences among groups $(P \leq 0.05)$

$\dagger$ Significant differences among groups $(P \leq 0.05)$, with yearlings differing from adults and fawns

cluded a whole-year analysis. However, fawns showed low prevalence in fall $(36.4 \%)$ that increased in winter and spring (both seasons with a $100 \%$ ), with the differences being significant $(P<0.05)$ (Fig. 2A). Differences in prevalence of $S$. asymmetrica/S. quadrispiculata among age groups were significant for fall, but not in winter. Again, in the fall, the differences among age categories were significant for mean intensity $(90 \%$; $P=0.0934)$, with fawns differing from yearlings and adults $(P$ $=0.05)$ (Fig. 2B). No seasonal changes were observed in the

A
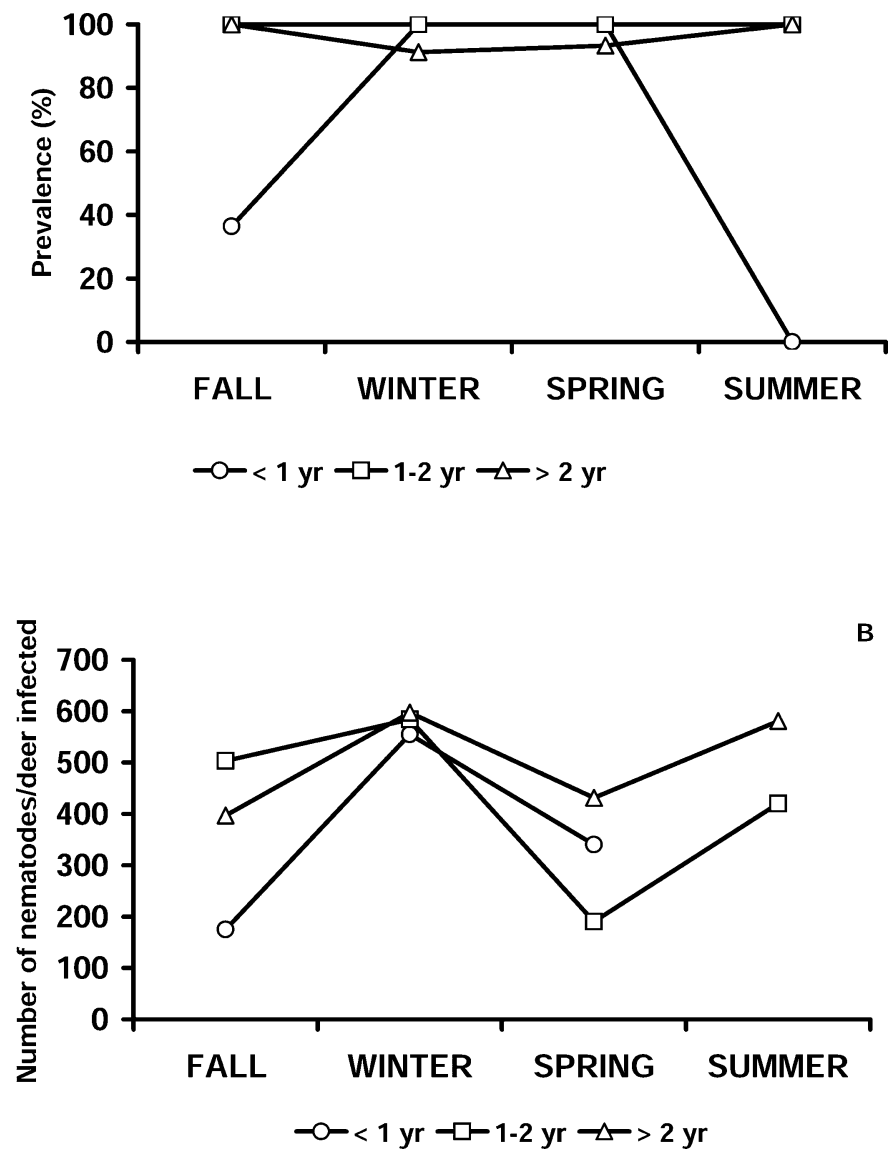

FiguRE 2. Seasonal prevalence (A) and mean intensity (B) of Spiculopteragia asymmetrica/Spiculopteragia quadrispiculata in the age groups considered of red deer. prevalence of $O$. leptospicularis/O. kolchida in adult deer, with consistent values near $70 \%$ through the year. However, the mean intensity $(P=0.0052)$ showed seasonal changes, with lower values in spring. Yearlings and adults had a high prevalence of O. leptospicularis/O. kolchida (Fig. 3A); however, in fawns we found a clearly higher prevalence in winter and spring than in fall. Intensity showed a parallel profile in yearlings and adults through the year, with higher values in yearlings (Fig. 3B). In fawns, mean intensity was very low in fall and increased in winter and spring; the only difference in intensity among age groups was found in winter $(P=0.0141)$.
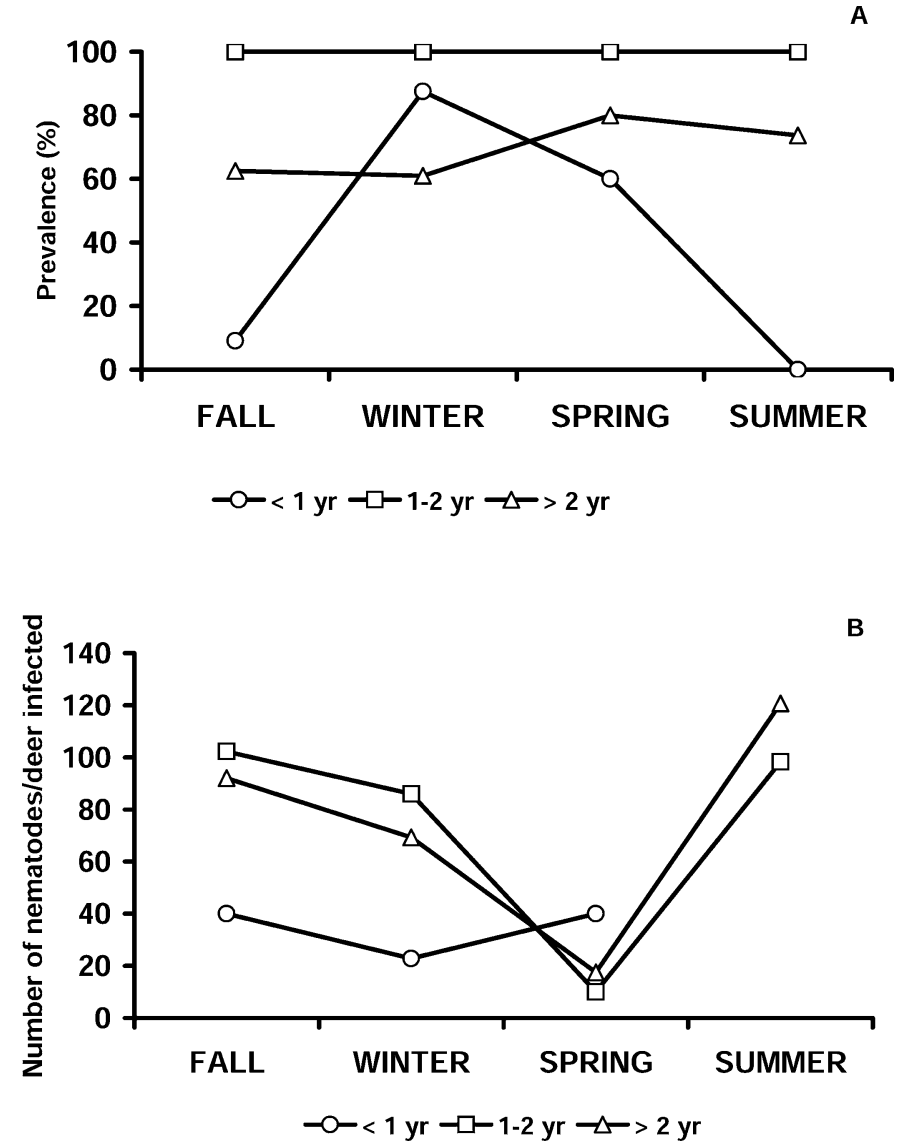

FiguRE 3. Seasonal prevalence (A) and mean intensity (B) of $O s$ tertagia leptospicularis/Ostertagia kolchida in the age groups considered of red deer. 

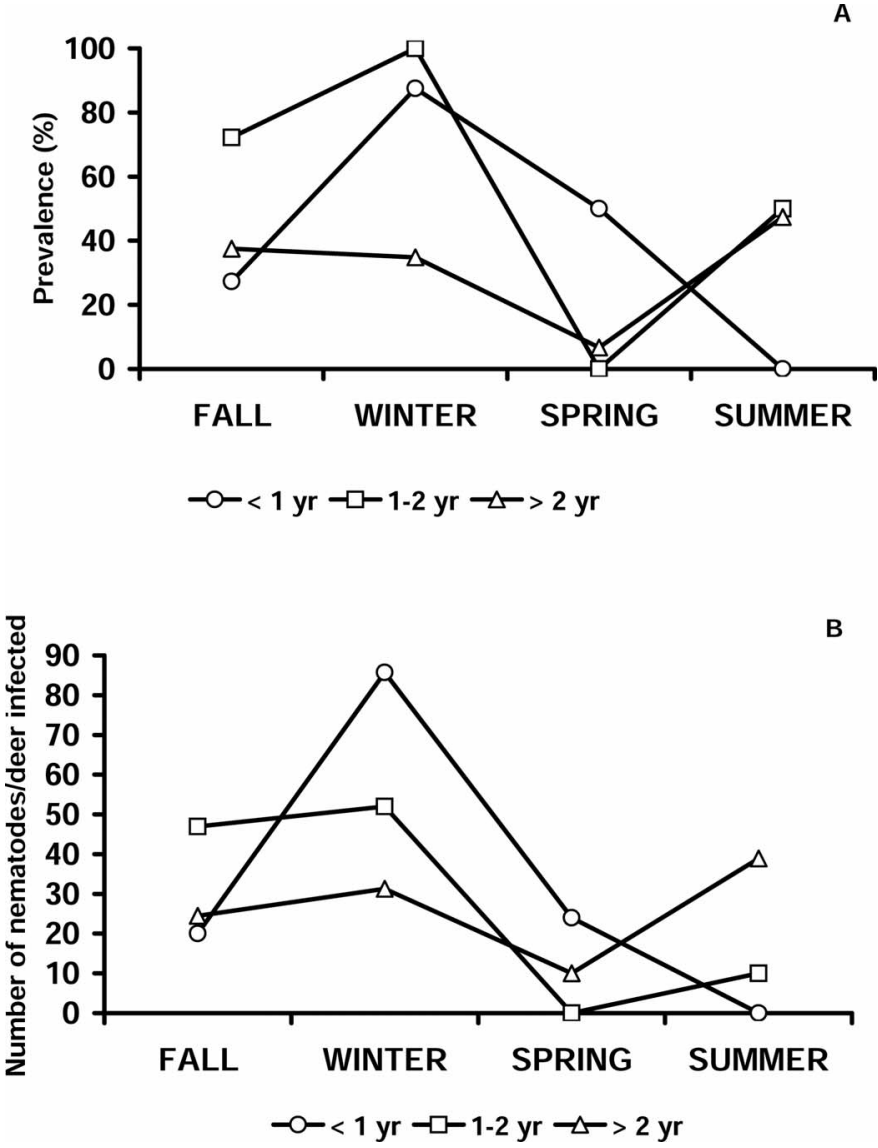

FIGURE 4. Seasonal prevalence (A) and mean intensity (B) of Ostertagia drozdzi/Ostertagia ryjikovi in the age groups considered of red deer.

The prevalence and mean intensity of $O$. drozdzi/O. ryjikovi were low during the year studied. The 2 parameters determined were lower in adult deer than in the other age groups; this was particularly clear in winter sampling (Fig. 4A, B). Seasonal pattern was roughly similar except for the fawns. Differences in the prevalence among age groups in the different seasons were significant in fall $(P=0.027)$ and winter $(P=0.003)$. No differences were observed between males and females for the prevalence of $S$. asymmetrica/S. quadrispiculata (Table III). Worm burdens were very stable through the year in females, with a slight increase in the mean intensity in spring (546.7 \pm 465.6 nematodes/animal). Males exhibited higher values in winter and, particularly, in summer, but the differences were not significant. In the case of $O$. leptospicularis/O. kolchida, sexrelated differences were not observed in any of the epidemiological indices, although parasitism tended to be higher in males. The average prevalence of $O$. drozdzilO. ryjikovi was slightly higher, but not significant, in males $(45 \%)$ than in females, with the exception of spring in which the males examined were not infected.

Data for the relative proportion of male morphotypes among single species of polymorphic ostertagiines revealed nearly constant ratios for major and minor forms through the year. In infrapopulations of male $S$. asymmetrica/S. quadrispiculata, the percentage represented by the $S$. asymmetrica morphotype (major) exhibited little variation $(\bar{x}=82.9 \pm 15.2)$. We did not see significant differences in the percentage of $S$. asymmetrica morphotype, or changes in relative abundance between major and minor morphotypes related to age, groups, or seasons. Among males of $O$. leptospicularis/O. kolchida, the major form ( $O$. leptospicularis) predominated ( $\bar{x}=98.6 \pm 7.9)$, and minor morphotypes were rare in all seasons, ages, and in both sexes. In populations of $O$. drozdzi/O. ryjikovi, the major morphotype ( $O$. drozdzi) predominated $(\bar{x}=80.5 \pm 33.0)$, and no significant differences were found in relation to age and sex of the animals or season. However, even when not significant, a reduction of the percentage of the $O$. drozdzi morph was observed in older animals $(86.7 \pm 27.3$ in fawns vs. $72.2 \pm 37.9$ in adults).

When determining the male/female ratio in the nematode infrapopulations from abomasa, some variations were found. Females of $S$. asymmetrica/S. quadrispiculata had an average percentage of $60.3 \pm 16.7$. No significant differences were found related to sex of the animals $(61.5 \pm 16.7$ in females vs. 64.6 \pm 13.9 in males). However, there were significant differences in percentage of female nematodes among age groups $(P=$ $0.0004)$, with a lower value in fawns than in yearlings and adults $(47.7 \pm 20.2$ in fawns vs. $62.4 \pm 13.1$ in yearlings and $63.0 \pm 15.4$ in adults). Fawns showed the lowest percentage of

TABLE III. Seasonal variation in prevalence $(\%)$ and intensity $( \pm \mathrm{SD})$ of Spiculopteragia asymmetrica/Spiculopteragia quadrispiculata, Ostertagia leptospicularis/Ostertagia kolchida, and Ostertagia drozdzi/Ostertagia ryjikovi in abomasa of male and female red deer (only adult red deer were considered).

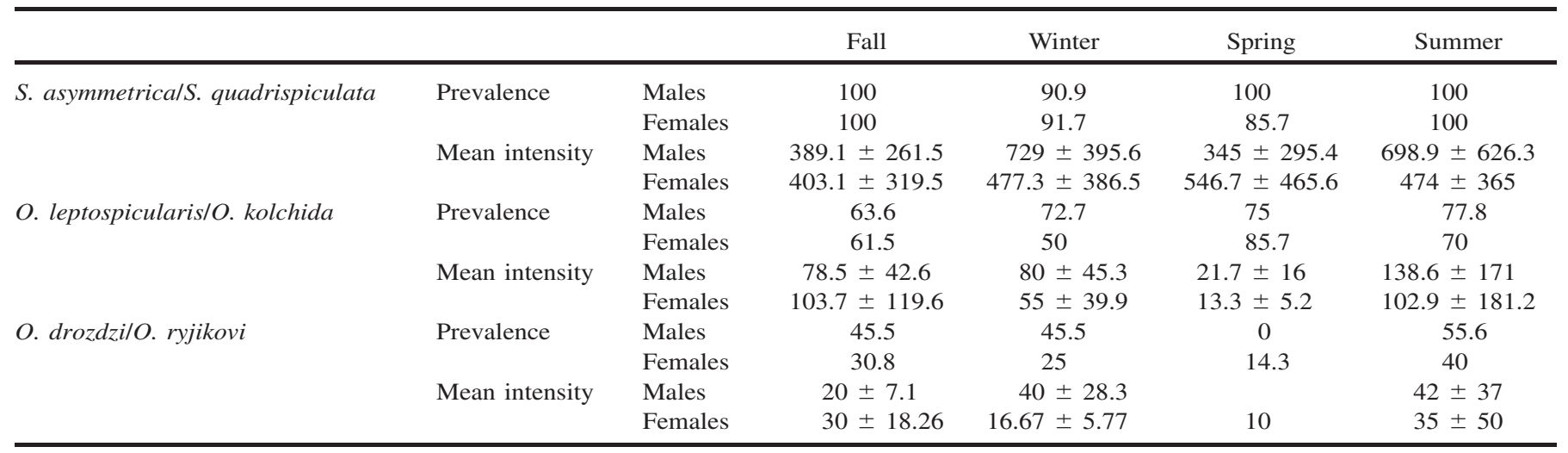


female nematodes in fall, when the difference between fawns and the other 2 groups ( $<1 \mathrm{yr}: 20 \pm 28.3 ; 1-2 \mathrm{yr}: 66.3 \pm 12.5$; $>2$ yr: $66.8 \pm 12.4)$ was also significant $(P=0.04)$.

Females of $O$. leptospicularis/O. kolchida had an average percentage of $56.2 \pm 31.0$. No significant differences were found related to sex $(59.1 \pm 36.6$ in females vs. $53.0 \pm 29.1$ in males) or age of the animals, but the percentage of female nematodes was lower in fawns $(51.2 \pm 33.7)$ than in yearlings $(59.1 \pm 26.3)$ and adults $(56.0 \pm 32.9)$. A lower percentage of female nematodes of $O$. leptospicularis/O. kolchida was found in spring $(36.5 \pm 37.5)$, and there were significant differences among seasons $(P=0.0117)$.

Females of $O$. drozdzi/O. ryjikovi had an average percentage of $53.9 \pm 36.5$. No significant differences were related with sex (51.9 \pm 48.1 in females vs. $57.6 \pm 33.7$ in males) or age of the animals, and season. However, although not statistically significant, the percentage of female nematodes showed a trend toward lower values in fawns than in yearlings and adults $(<1$ yr: $38.6 \pm 28.6 ; 1-2$ yr: $62.0 \pm 35.0 ;>2$ yr: $55.0 \pm 40.0$ ).

\section{DISCUSSION}

\section{Parasitism and age classes}

Abomasal helminth infections in the red deer examined in Quintos de Mora were prevalent (93\%), with a moderate mean intensity (553 nematodes/deer infected). A high prevalence of abomasal infection, close to a $100 \%$, and moderate intensity of infection appears to be typical among surveys for parasites in wild cervids (Ambrosi et al., 1993; Dróżdż et al., 1993, 1994; Zaffaroni et al., 1996; Dróżdż et al., 1997; Rossi et al., 1997; Suárez et al., 1997; García Romero et al., 2000; Irvine et al., 2006). Additionally, in these studies, as in red deer at Quintos de Mora, there were no significant differences in intensity of infection related to sex of host, although, in most cases, intensity of infection in males exceeds that observed in females. In our study, nematode burdens may have been underestimated as we did not sample or recover fourth-stage larvae (L4) that may have been present as arrested populations in red deer at Quintos de Mora. Such L4, potentially arrested in the abomasum, have been reported in white-tailed deer by other authors (Belem et al., 1993; Kitamura et al., 1997).

Multispecies infections by helminths in the abomasum are characteristic of cervids, as it was in our study. Nematodes identified in this study belonged to 4 species, i.e., $S$. asymmetrica/S. quadrispiculata, O. leptospicularis/O. kolchida, O. drozdzi/O. ryjikovi, and Trichostrongylus axei. All species of abomasal nematodes recovered in the present study have been reported previously in red deer from Spain (Santín-Durán et al., 2004). The 3 polymorphic species of Ostertagiinae identified, all typical parasites of cervid hosts, were prevalent and abundant, whereas $T$. axei was found only in 2 deer. Greater species richness for nematode communities in cervids has been reported from other areas of Europe, perhaps due to co-occurrence of red deer with other sympatric artiodactyls (Dróżdż et al., 1997).

No evidence of a general age-acquired resistance to abomasal nematodes emerged from our data for total infection. Similar results were observed for abomasal infection in sheep (DíezBaños et al., 1992) and some cervids (fallow deer, roe deer, and reindeer, Rangifer tarandus [Linnaeus]), where higher worm burdens were observed in adult hosts (Dunn, 1965; Dróżdż et al., 1987; Ambrosi et al., 1993; Rossi et al., 1997; Zaffaroni et al., 1997; Halvorsen and Bye, 1999; Irvine et al., 2000). On the contrary, O. drozdzi/O. ryjikovi was less prevalent, and the intensity of the infection was lower in older hosts. Moreover, the percentage of $O$. drozdzi/O. ryjikovi was significantly higher in fawns than in other older groups. Whether or not there is an age-acquired resistance to this species, O. drozdzi/O. ryjikovi, but not for the others (O. leptospicularis/O. kolchida and $S$. asymmetrica/S. quadrispiculata), needs additional research given the low helminth burdens found in this study for Ostertagia spp.

\section{Seasonal dynamics of infection}

The sampling method from our study (necropsy of animals from selective hunting) precluded the followup of abomasal parasitism along the year in a cohort group. Moreover, in some cases the available number of deer from an age group was low, thus rendering the comparisons very difficult. However, generally speaking, variation in prevalence of abomasal infection was not observed in red deer at Quintos de Mora during the annual cycle, whereas intensity of infection showed an apparent bimodal pattern. Ambient conditions for temperature and humidity in the region would be predicted to promote the development of free-living preparasitic stages in the colder (and more humid) months of the year. We suggest that the second peak is an artifact of management practices, where development of larvae and transmission may reflect the use of irrigated areas to supplement the diet during the summer. These pastures, besides allowing the development of infective larvae, would promote higher density for red deer and, therefore, influence the risks of acquiring infective stages while grazing. A direct relationship between host density and parasite burdens has been observed in deer populations previously (Suárez et al., 1997; Santín-Durán et al., 2004), but this artificial condition and supplemental grazing may represent a positive feedback mechanism that influences transmission and parasitism.

The seasonal pattern observed was almost entirely due to the population dynamics for $S$. asymmetrica/S. quadrispiculata, because this species represented over $80 \%$ of the nematodes present in the abomasa of infected animals. It is possible that the different patterns found for O. leptospicularis/O. kolchida and the congeneric $O$. drozdzi/O. ryjikovi are artifacts and dependent on the low intensity of both species.

Interpretation of our results on the seasonality of abomasal infections is problematic given the scarce number of reports covering a full year and the variability of climatic conditions affecting patterns in transmission across different regions (Dróżdż et al., 1993; Rossi et al., 1997). In Poland, a higher intensity of abomasal infection in spring for red deer was found (Dróżdż et al., 1993), whereas in roe deer the highest intensity occurred in August (Dróżdż et al., 1987, 1992). In Italy, a pattern similar to ours was observed for abomasal infections in roe deer (Rossi et al., 1997). In an area similar to that where our study was conducted, García Romero et al. (2000) reported higher intensities in red deer in summer and fall, the differences perhaps due to management practices in both cases.

The general pattern found was also observed in adults and yearlings, but not in fawns. Among fawns, notable differences 
in the total worm burdens are observed, with an increase from fall in prevalence and intensity, reaching levels comparable to those in older animals by the spring. This pattern appears to reflect the cumulative nature of infections for abomasal nematodes in red deer. At Quintos de Mora, fawns are born at the end of May and June and lactation occurs during summer, thus explaining the absence of parasitized fawns in this season given the long lactation period (4-5 mo) (Montoya Olivier, 1999; García et al., 2001). Grazing for fawns usually commences in the fall and would lead to acquisition of abomasal nematodes, representing those occurring in subadult hosts in the following year. Similar patterns have been documented for gastrointestinal nematodes in fallow deer (Kotrlá and Kotrlỳ, 1975) and reindeer (Halvorsen and Bye, 1999; Irvine et al., 2000).

\section{Relative abundance of Ostertagiinae and their male morphotypes}

The relative abundance of respective major and minor morphotype for males among the 3 species of Ostertagiinae revealed minimal intraspecific variation, but substantial and nearly constant interspecific differences. Among deer sampled at Quintos de Mora, the major morphotypes, S. asymmetrica, O. leptospicularis, and $O$. drozdzi, represented, respectively, $83 \%$, $99 \%$, and $81 \%$, of the total populations of males for each species. Variation in the ratio of male morphotypes has been observed in roe deer for $O$. leptospicularis/O. kolchida (males of O. kolchida:males of O. leptospicularis, 1:2.8) and Spiculopteragia spiculoptera (Guschanskaia, 1931)/Spiculopteragia mathevossiani Ruchliadev, 1948 (males of S. spiculoptera: males of S. mathevossiani, 1:75) (Dróżdż et al., 1992). The ratio within a species has a tendency to be constant (Morales and Cabaret, 1995), although some variations have been observed associated with season, geographic area, and host (Dróżdż, 1995; Suárez et al., 1995). In the present study, variation related to the sex and age of the hosts was not observed. The only exception was the apparent increase among older animals in the relative abundance of the minor morphotype for $O$. drozdzi/O. ryjikovi. Dróżdż et al. (1987) also found a higher proportion of the minor morphotype $S$. mathevossiani in older roe deer, but they did not find differences for O. leptospicularis/O. kolchida.

We observed no differences in relative abundance for respective morphotypes for these ostertagiines relative to the season of collection. In contrast, Dróżdż et al. (1987) and Dróżdż et al. (1992) observed that season affected the ratio of males for S. spiculoptera/S. mathevossiani in roe deer (a higher proportion of the minor morphotype $S$. mathevossiani in August and October than in January and May), although no differences were found for $O$. leptospicularis/O. kolchida. In the related Teladorsagia boreoarcticus Hoberg, Monsen, Kutz and Blouin, 1999 , it has been shown that the relative proportion of minor morphotype males increases through the winter at high-latitude sites in the central Canadian Arctic (Hoberg et al., 1999); this could reflect senescence within populations of nematodes in single hosts. Additionally, a higher proportion of the minor morphotypes for $S$. asymmetrica/S. quadrispiculata and $O$. drozdzilO. ryjikovi was found in sympatric fallow deer from Quintos de Mora (Santín-Durán et al., 2004). It is possible that this may be related to fallow deer being the principal cervid host for $S$. asymmetrica/S. quadrispiculata and O. drozdzi/O. ryji- kovi (Dróżdż, 1995). Overall, the genetic/environmental basis for what appears to be a balanced polymorphism within single species of ostertagiines has yet to be determined (Dróżdż, 1995).

\section{Patterns of abundance for male and female nematodes}

Relative abundance of male and female nematodes representing the 3 species of ostertagiines in single hosts appeared to be biased. Among red deer at Quintos de Mora, female nematodes were predominant, and represented $60 \%, 56 \%$, and $54 \%$, respectively, for total populations of $S$. asymmetrica/S. quadrispiculata, O. leptospicularis/O. kolchida, and O. drozdzi/O. ryjikovi. It is difficult to compare our results with those of previous investigations of cervid parasites because most studies only identified males. However, this female bias has also been observed in reindeer for populations of Ostertagia gruehneri Skrjabin, 1929 and Marshallagia marshalli (Ransom, 1917) and in fallow deer for $S$. asymmetrica/S. quadrispiculata and $O$. drozdzi/O. ryjikovi (Santín-Durán et al., 2004; Stien et al., 2005). The ratio of male/female nematodes was rather constant within each species through the year in red deer from Quintos de Mora. On the other hand, in fawns the percentage that female nematodes represented was lower than in adults in all the species; differences were only significant for $S$. asymmetrica/S. quadrispiculata. A decrease in ratios for male and female nematodes with the age of the host has been considered an indicator of senescence within a nematode population (Halvorsen and Bye, 1999) given the longer life expectancy of female worms (Poulin et al., 1997). The suggestion seems reasonable, because fawns showed an increased ratio from the time they acquired the first infections (fall) extending into spring, when relative abundance is comparable to that found in adult hosts. These results suggest that the percentage of female nematodes in an animal increases after the first infection to reach a stable value for each of the Ostertagiinae species. Further, this may suggest that relative contribution of eggs and larvae on pasture could be greater for adult hosts that harbor larger populations of female nematodes.

\section{ACKNOWLEDGMENTS}

We appreciate the cooperation of J. M. Sebastián and C. Rodríguez and the warden services of the Los Quintos de Mora (Toledo) park. The sampling was made possible by the help of J. M. San Miguel, I. Domínguez, A. López, A. González, and M. Carballo. Some laboratory studies by M.S.D. with E.P.H. were completed at the U.S. National Parasite Collection, and we gratefully acknowledge assistance from P. A. Pilitt and A. Abrams. Research was partially funded by CGL200402580-CO3-02 and FAU2006-00008-00-00 projects.

\section{LITERATURE CITED}

Álvarez, G. 1988. Problemas asociados a la aplicación del transecto lineal para el censo de las poblaciones de cérvidos en un biotopo mediterráneo (Quintos de Mora, Montes de Toledo). Ecología 2: 233-249.

— stag (Cervus elaphus L.) and its relationship to morphology and habitat in central Spain. Folia Zoologica 40: 117-130.

Ambrosi, M., M. T. Manfredi, And P. LANFranchi. 1993. Pattern of abomasal helminths in fallow deer farming in Umbria (central Italy). Veterinary Parasitology 47: 81-86.

BARTH, D., AND P. MATZKE. 1984. Gastro-intestinal nematodes of fallow deer (Dama dama L.) in Germany. Veterinary Parasitology 16: 173-176. 
Batty, A. F., D. I. Chapman, And N. Chapman. 1987. Prevalence of nematode parasites in wild fallow deer (Dama dama). The Veterinary Record 120: 599.

Belem, A. M. G., C. E. Couvillion, C. Siefker, and R. N. Griffin. 1993. Evidence for arrested development of abomasal nematodes in white-tailed deer. Journal of Wildlife Diseases 29: 261-265.

Díez-Baños, N., J. CABaret, and P. Díez-Baños. 1992. Interspecific interactions in naturally acquired nematode communities from sheep abomasum in relation to age of host and season in four areas of León (Spain). International Journal for Parasitology 22: 327334.

DiXON, W. P. 1993. BMDP statistical software manual. University of California Press, Berkeley, California, 1,500 p.

DRóżDż, J. 1995. Polymorphism in the Ostertagiinae López-Neyra, 1947 and comments on the systematics of these nematodes. Systematic Parasitology 32: 91-99.

- A. W. DemiaszKiewicz, And J. Lachowicz. 1992. The helminth fauna of the roe deer Capreolus capreolus (L.) in a hunting area inhabited by red deer, elk and European bison (Borecka Forest, Poland) over the yearly cycle. Acta Parasitologica 37: 83-88.

- — AND - 1993. Seasonal changes in the helminth fauna of Cervus elaphus (L.) from Slowinski National Park (Poland). Acta Parasitologica 38: 85-87.

— $—$ AND — 1994. The effect of culling red deer, Cervus elaphus (L.), on their helminth fauna in the Slowinski National Park (Poland). Acta Parasitologica 39: 92-94.

- J. Lachowicz, A. W. Demiaszkiewicz, and T. Sulgostowska. 1987. Abomasum nematodes in field and forest roe deer Capreolus capreolus (L.) over a yearly cycle. Acta Parasitologica Polonica 32: $339-348$

- A. Malczewsini, A. W. Demiaszkiewicz, and J. Lachowicz. 1997. The helminthofauna of farmed deer (Cervidae) in Poland. Acta Parasitologica 42: 225-229.

DunN, A. M. 1965. The gastro-intestinal helminths of wild ruminants in Britain. I. Roe deer, Capreolus capreolus capreolus. Parasitology 55: 739-745.

García, A., T. Landete-Castillejos, J. Garde, and L. Gallego. 2001. Aspectos reproductivos y productivos en el ciervo ibérico (Cervus elaphus hispanicus). Pequeños Rumiantes 2: 22-26.

García-Romero, C., F. Valcárcel, J. Corchero, A. S. Olmeda, and J. M. PÉREZ. 2000. Contribución al estudio de las parasitosis del ciervo (Cervus elaphus) en las provincias de Toledo y Ciudad Real (Castilla-La Mancha, España). Ecología 14: 235-249.

Halvorsen, O., AND K. BYE. 1999. Parasites, biodiversity, and population dynamics in an ecosystem in the high arctic. Veterinary Parasitology 84: 205-227.

Hernández, S., F. Martínez, R. Calero, T. Moreno, and I. NavarRETE. 1980. Parásitos del ciervo (Cervus elaphus) en Córdoba. I. Primera relación. Revista Ibérica de Parasitología 40: 93-106.

Hoberg, E. P., K. J. Monsen, S. KuTs, AND M. S. Blouin. 1999. Structure, biodiversity, and historical biogeography of nematode faunas in holartic ruminants: Morphological and molecular diagnosis for Teladorsagia boreoarcticus $\mathrm{n}$. sp. (Nematoda: Ostertagiinae), a dimorphic species in muskoxen (Ovibos moschatus). Journal of Parasitology 85: 910-934.

Irvine, R. J., H. Corbishley, J. G. Pilkington, and S. D. Albon. 2006. Low-level parasitic worm burdens may reduce body condition in free-ranging red deer (Cervus elaphus). Parasitology 133: 465-475.

- A. Stien, O. Halvorsen, R. Langvatn, and S. D. Albon. 2000. Life-history strategies and population dynamics of abomasal nematodes in Svalbard reindeer (Rangifer tarandus platyrhynchus). Parasitology 120: 297-311.

JANČEV, J. 1979. Helminths in the fallow deer (Dama dama L.) in the Voden and Krichim Hunting Preserves. Helminthologia 8: 64-82.
Kitamura, E., Y. Yokohata, M. Suzuki, and M. Kamiya. 1997. Metazoan parasites of sika deer from east Hokkaido, Japan and ecological analyses of their abomasal nematodes. Journal of Wildlife Diseases 33: 278-284.

KotrLÁ, B., AND A. KotrLỲ. 1975. Development of the helminth fauna of the Dama dama in the Brezka game preserve. Acta Veterinaria Brno 44: 235-244.

Margolis, L., G. W. Esch, J. C. Holmes, A. M. Kuris, and G. A. SCHAD. 1982. The use of ecological terms in parasitology (report of an ad hoc committee of the American Society of Parasitologists). Journal of Parasitology 68: 131-133.

Ministry of Agriculture, Fisheries, AND Food. 1971. Manual of veterinary parasitological techniques. Her Majesty's Stationery Office, London, U.K., 131 p.

Montoya-Olivier, J. M. 1999. El ciervo y el monte: Manejo y conservación (Cervus elaphus L.). Fundación Conde del valle de Salazar y Ediciones Mundi-Prensa, Madrid, Spain, 292 p.

Morales, G., AND J. CABARET. 1995. Determinación de las relaciones polimórficas entre Teladorsagia circumcincta (Stadelman, 1894) y Teladorsagia trifurcata (Ransom, 1907) en condiciones experimentales. Memoires de Instituto Oswaldo Cruz, Rio de Janeiro 80: 8590.

Poulin, R. 1997. Population abundance and sex ratio in dioecious helminth parasites. Oecologia 111: 375-380.

Rossi, L., B. Eckel, and E. Ferroglio. 1997. A survey of gastrointestinal nematodes of roe deer (Capreolus capreolus) in a mountain habitat. Parassitologia 39: 303-312.

Santín-Durán, M., J. M. Alunda, E. P. Hoberg, and C. de la Fuente. 2004. Abomasal parasites in wild sympatric cervids, red deer, Cervus elaphus and fallow deer, Dama dama, from three localities across central and western Spain: Relationship to host density and park management. Journal of Parasitology 90: 1378-1386.

Sanz de la Torre, V., E. Martínez del Valle, and P. Fandos. 1993. Datos básicos para la elaboración de un plan de gestión de la población de ciervo (Cervus elaphus) en Los Quintos de Mora (Los Yébenes-Toledo). Ministerio de Agricultura, Pesca y Alimentación. Instituto Nacional para la Conservación de la Naturaleza, Servicio Territorial de Castilla La Mancha, Madrid, Spain.

Stien, A., M. Dallimer, R. J. Irvine, O. Halvorsen, R. Langvatn, S. D. Albon, AND J. F. Dallas. 2005. Sex ratio variation in gastrointestinal nematodes of Svalbard reindeer; density and implications for estimates of species composition. Parasitology 130: 99-107.

SuÁrez, V. H., J. CABARET, AND L. Gruner. 1995. Morphological polymorphism in the nematode Teladorsagia circumcincta in relation to age of larvae, infection mode and lamb characteristics in experimental conditions. International Journal for Parasitology 25: 11731177.

, G. C. Mereb, R. M. Lorenzo, M. R. Busetti, And M. C. Fort. 1997. Parásitos internos hallados en ciervo colorado (Cervus elaphus L.) en la provincial de La Pampa (Argentina). Revista de Medicina Veterinaria 78: 77-80.

Tellería, J. L., AND C. Sáez-Royuela. 1984. The large mammals of central Spain. An introductory view. Mammal Review 14: 51-56.

Wilson, D. E., AND D. M. REEDER. 1993. Mammal species of the world: A taxonomic and geographic reference, 2nd ed. Smithsonian Institution Press, Washington, D.C., 1,207 p.

Zaffaroni, E., C. CitTerio, M. Sala, and S. Lauzi. 1997. Impact of abomasal nematodes on roe deer and chamois body condition in an alpine environment. Parassitologia 39: 313-317.

, C. Fraquelli, M. T. Manfredi, A. Siboni, P. Lanfranchi, E. SARTORI, AND P. PARTEL. 1996. Abomasal helminth communities in eastern alpine sympatric roe deer (Capreolus capreolus) and chamois (Rupicapra rupicapra) populations. Supplemento alle Ricerche di Biologia della Selvaggina 24: 53-68. 